Antarctic Science 26(6), 661-673 (2014) @ Antarctic Science Ltd 2014. This is an Open Access article, distributed under the terms of the Creative Commons Attribution licence (http://creativecommons.org/licenses/by/3.0/), which permits unrestricted re-use, distribution, and reproduction in any medium, provided the original work is properly cited.

\title{
Ice shelf history determined from deformation styles in surface debris
}

\author{
NEIL F. GLASSER ${ }^{1}$, TOM HOLT ${ }^{1}$, ED FLEMING ${ }^{2}$ and CARL STEVENSON ${ }^{2}$ \\ ${ }^{1}$ Centre for Glaciology, Department of Geography and Earth Sciences, Aberystwyth University, Aberystwyth SY23 3DB, UK \\ ${ }^{2}$ School of Geography, Earth and Environmental Sciences, University of Birmingham, Birmingham B15 2TT, UK \\ nfg@aber.ac.uk
}

\begin{abstract}
This paper presents InSAR-derived ice shelf velocities and observations of surface debris deformation on the McMurdo Ice Shelf (MIS). Ice shelf velocities show that the MIS has a low surface velocity, with debris-laden parts of the ice shelf in the area known as the 'swirls' averaging speeds of c. $3 \mathrm{~m} \mathrm{a}^{-1}$ increasing to $c .16 \mathrm{~m} \mathrm{a}^{-1}$ at the ice front. Analysis of the fold patterns within moraine ridges on the ice surface reveals a deformational history inconsistent with the present velocity measurements. Polyphase, isoclinal folding within moraine ridges at the surface are interpreted to have formed through intense deformation by past ice flow in a NNW orientation. The velocities and styles of deformation indicate that the majority of debris on the ice shelf was originally transported into the area by a large and dynamic ice sheet/ice shelf system entirely different to that of the present configuration. Although the age of this event is unknown, it is possible that this debris has been exposed on the surface of the ice shelf since the last glacial maximum.
\end{abstract}

Received 30 August 2013, accepted 31 March 2014

Key words: Antarctica, geomorphology, glaciology, Quaternary

\section{Introduction}

The aim of this paper is to provide insight into the flow regime and dynamics of the McMurdo Ice Shelf (MIS) by interpreting styles of surface debris deformation. Descriptions of ice surface debris and its deformational history (as mapped from remotely sensed images), structural observations and ice-surface velocity measurements are used to infer the past and current deformational regimes in the MIS, and to comment on ice shelf stability. Ice shelves are an essential component of the mass balance of the Antarctic ice sheet for three main reasons. First, ice shelves play a significant role in the global ice volume/sea level system because over $90 \%$ of Antarctic ablation occurs through iceberg calving and basal melting from ice shelf systems (Vaughan \& Doake 1996, MacAyeal et al. 2003, Rignot et al. 2013). Several smaller Antarctic ice shelves have significantly retreated in recent years (Rack \& Rott 2004, Cook \& Vaughan 2010); illustrating their sensitivity to atmospheric (Vaughan et al. 2003, Barrand et al. 2013) and oceanic (Meredith \& King 2005) warming, leading to ice shelf thinning (Pritchard et al. 2012), ice sheet instability (Hillenbrand et al. 2013) and potentially reduced sea ice thickness (Stammerjohn et al. 2008). Second, basal melting in ice shelf cavities has a significant impact on the global ocean heat budget and there is rapid heat exchange between ice shelves and the oceans (Jacobs et al. 1992, Joughin \& Padman 2003, Albrecht et al. 2006, Craven et al. 2009, Pritchard et al. 2012). The outflow of supercooled water from beneath ice shelves is also known to influence sea ice formation processes (Hellmer, 2004, Purdie et al. 2006, Gough et al. 2012). Third, ice shelves control the dynamics and, therefore, the system response time of upstream inland ice in Antarctica (De Angelis \& Skvarca 2003). There is abundant evidence that both feeder glaciers and former ice shelves have responded rapidly to ice shelf removal through velocity increases (Rignot et al. 2004, Scambos et al. 2004), ice surface lowering (Berthier et al. 2012) and ice front recession (Glasser et al. 2011). There is also evidence that iceberg calving events from ice shelves occurred periodically throughout the Quaternary (Hulbe et al. 2004).

The MIS is a small ice shelf $\left(c .4000 \mathrm{~km}^{2}\right.$ with an ablation area of $c .1500 \mathrm{~km}^{2}$ ) at the southern end of the McMurdo Sound in the Ross Sea sector of Antarctica (Fig. 1). The ice shelf is subject to strong west-east gradients in both atmospheric and oceanographic conditions. As a consequence, and because of a complex pattern of ice supply from the surrounding areas, the ice shelf has an unusual surface flow pattern. The western MIS moves very slowly as there is little input of ice from grounded catchment basins or other ice shelf areas (Swithinbank 1970). Using a combination of sedimentological descriptions, ground-penetrating radar investigations, and ablation, velocity and ice thickness measurements during the 2003-04 summer, Glasser et al. (2006) showed that the ice shelf moves relatively slowly $\left(1.5-18.3 \mathrm{~m} \mathrm{a}^{-1}\right)$, has high surface ablation rates $(43-441 \mathrm{~mm})$ and is locally thin $(6-22 \mathrm{~m})$. 


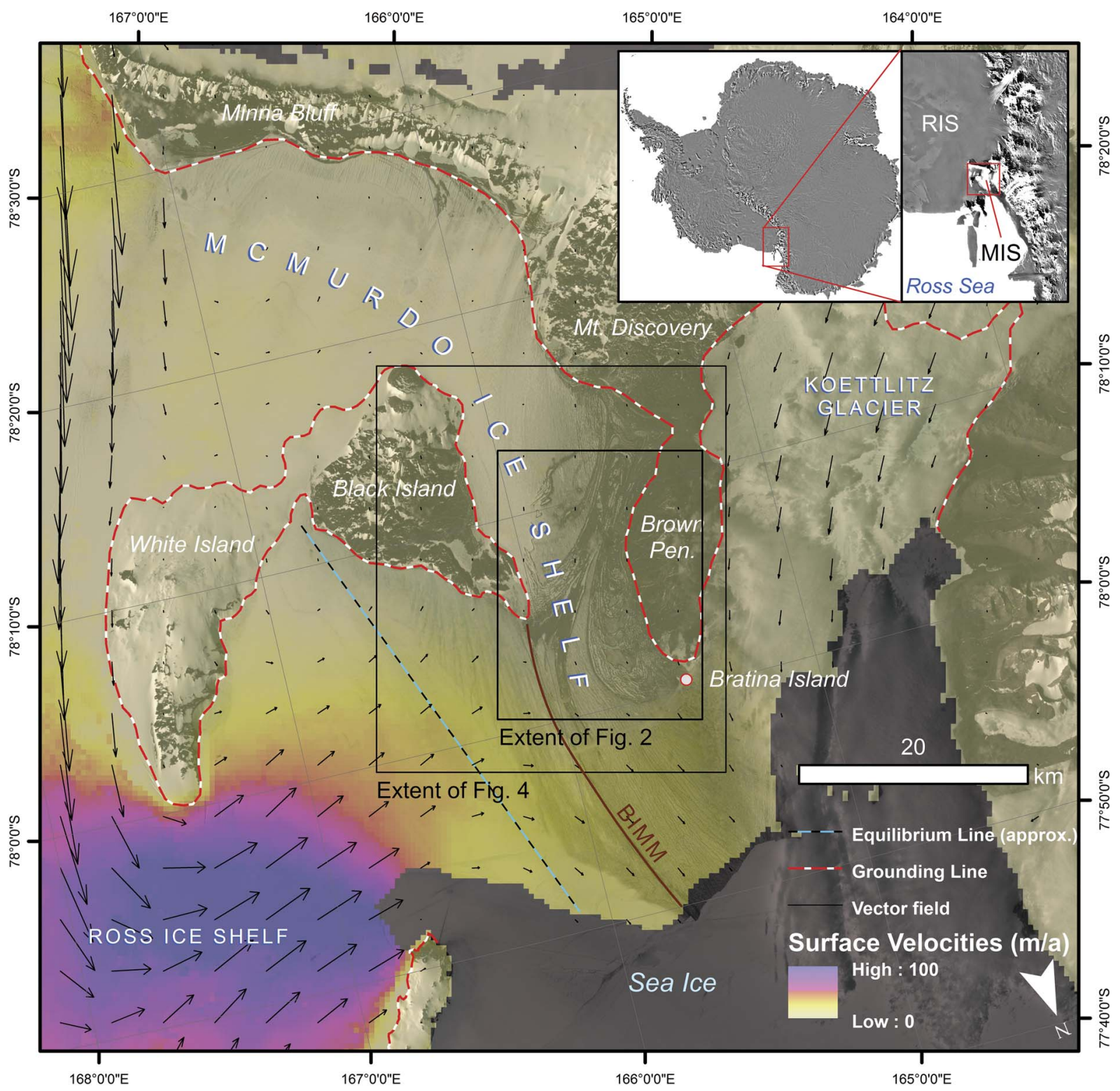

Fig. 1. Ice-surface velocities and vectors on the McMurdo Ice Shelf derived from InSAR (Rignot et al. 2011). The position of the grounding line is taken from the Bedmap2 dataset (Fretwell et al. 2013). Note that ice surface velocities are almost negligible in the debris-covered area known as the 'swirls', between Brown Peninsula and Black Island. BIMM = Black Island medial moraine, MIS = McMurdo Ice Shelf, RIS = Ross Ice Shelf.

The surface accumulation on the MIS strongly decreases from east-west. Frequent melting occurs in the central and western parts, whereas the eastern areas are part of the dry snow zone. The equilibrium line runs approximately North-South from $166.10^{\circ} \mathrm{E} / 77.85^{\circ} \mathrm{S}$ to $166.80^{\circ} \mathrm{E} / 78.20^{\circ} \mathrm{S}$ (Swithinbank 1970). There are few measurements of ablation on the western MIS, but field data collected in 2003-04 show summer ablation rates from $43-441 \mathrm{~mm}$ (Glasser et al. 2006). Ablation is a consequence of the prevailing southwesterly winds, which are adiabatically warmed as they descend from Minna Bluff and Mount Discovery and pass across the ice surface. The MIS supports one of the largest areas of meltwater in the Ross Sea sector of Antarctica. Each summer approximately $25 \%$ of the ice shelf is covered in streams, ponds and small lakes. Meltwater varies from fresh to hypersaline and fills hollows in the highly raised surface topography amongst widespread patches of debris (Pridmore et al. 1995). Some ponds are clear, whilst others support thick cyanobacteria mats (algal mats) (Hawes et al. 1999).

The strong surface ablation on the western MIS is balanced by basal freezing elsewhere (Debenham 1965, Kellogg et al. 1990, Fitzsimons et al. 2012) as a 


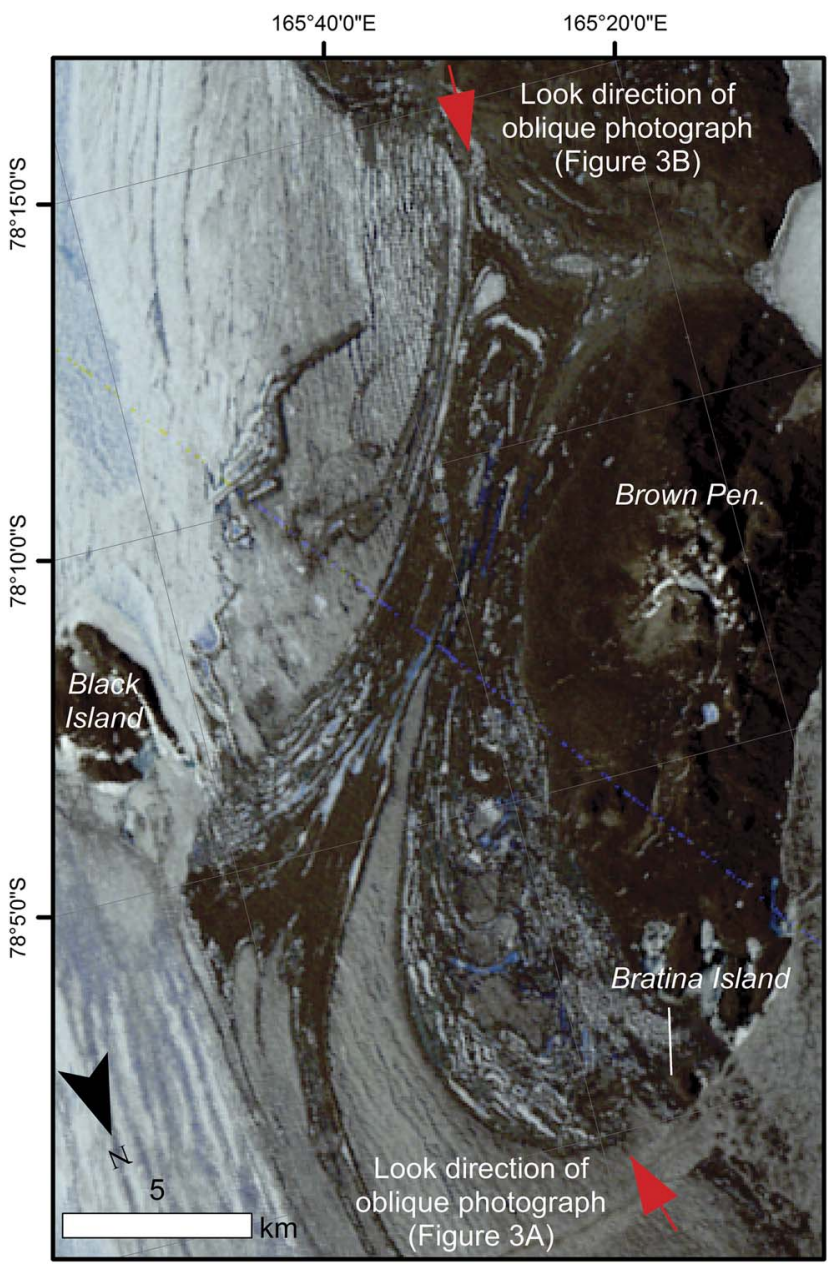

Fig. 2. Detail of ASTER satellite image from 2001 showing the 'swirls' area of the McMurdo Ice Shelf.

consequence of seasonal oceanic regimes in the ice shelf cavity (Robinson et al. 2010, Leonard et al. 2011, Mahoney et al. 2011, Stern et al. 2013). A persistent feature is a tongue of platelet ice on the western side of the sound, which is the result of supercooled water carrying ice crystals from beneath the MIS (Dempsey et al. 2010, Mager et al. 2013).

Glaciological measurements made on the MIS between 1960 and 1984, including ice thickness measurements, are summarized by McCrae (1984). Radio-echo soundings of ice thickness in the ablation zone are in the general range of 10-50 m (Swithinbank 1970). These estimates have been independently verified by seismic soundings (Cook 1963), airborne investigations (Rack et al. 2013) and ice drilling (Gow 1967). Recent investigations using ice-penetrating radar, closer to the ice front, are in the range 6-22 m (Glasser et al. 2006).

There is intrusion of brine into the central parts of the ice shelf (Kovacs \& Gow 1975, Kovacs et al. 1982). The combination of seawater and sediment freezing onto

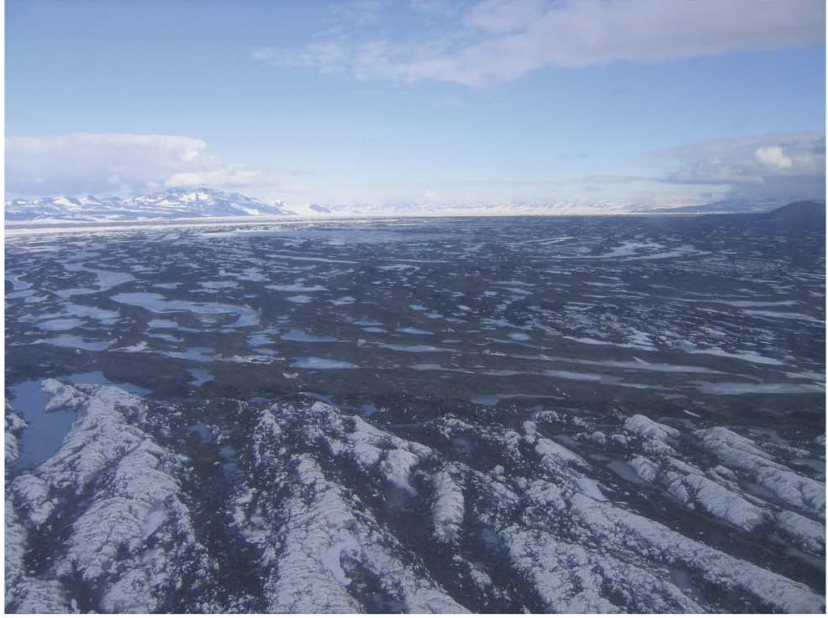

a

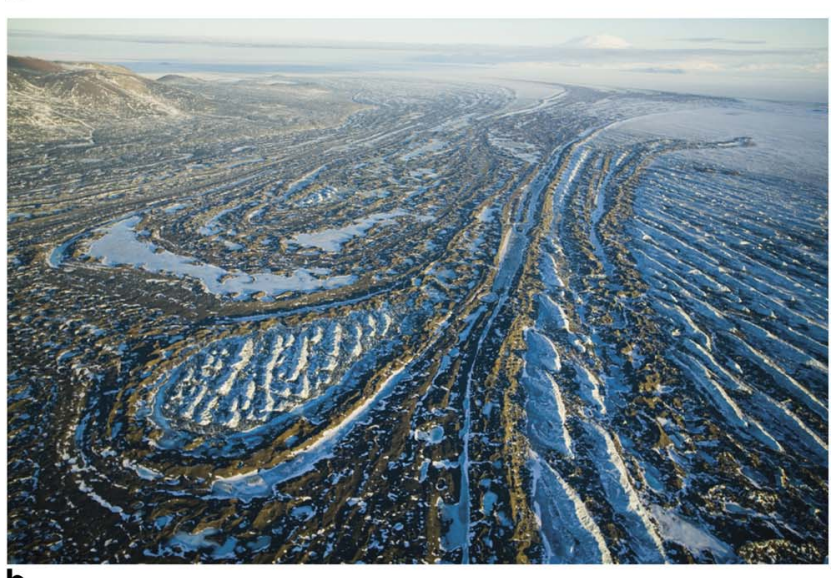

b

Fig. 3. a. Oblique aerial photograph of the 'swirls' area in January 2004 showing debris on the ice shelf surface (Photograph: Neil Glasser). b. Oblique aerial photograph showing detail of teardrop-shaped folded moraine ridges in the 'swirls' area in 2011 (Photograph: George Steinmetz). Photograph locations are indicated in Fig. 2.

the base of the ice shelf and high surface ablation causes a net upward migration of ice and debris, allowing debris to become concentrated on the ice surface (Debenham 1961, 1965). Debenham (1919) was the first to describe the debris on the MIS, in particular the occurrence of marine biota including fish, sponges, starfish and shells. Subsequent work on the marine biota and sediments of the ice shelf includes Swithinbank et al. (1961), Speden (1962), Gow et al. (1965), Kellogg et al. (1977, 1990), Brady (1978), Hayward \& Taylor (1984), Kellogg \& Kellogg (1984, 1987a, 1987b, 1988), Hart (1990) and Wilson (2000).

Kellogg et al. (1990) recognized two distinctly different types of debris band on the MIS. The first group is characterized by thin (usually $<10 \mathrm{~cm}$ ) debris overlying clean ice, in which marine shells yield ${ }^{14} \mathrm{C}$ ages up to $7700 \mathrm{yr}$ BP. Ice underlying debris in this young group of 

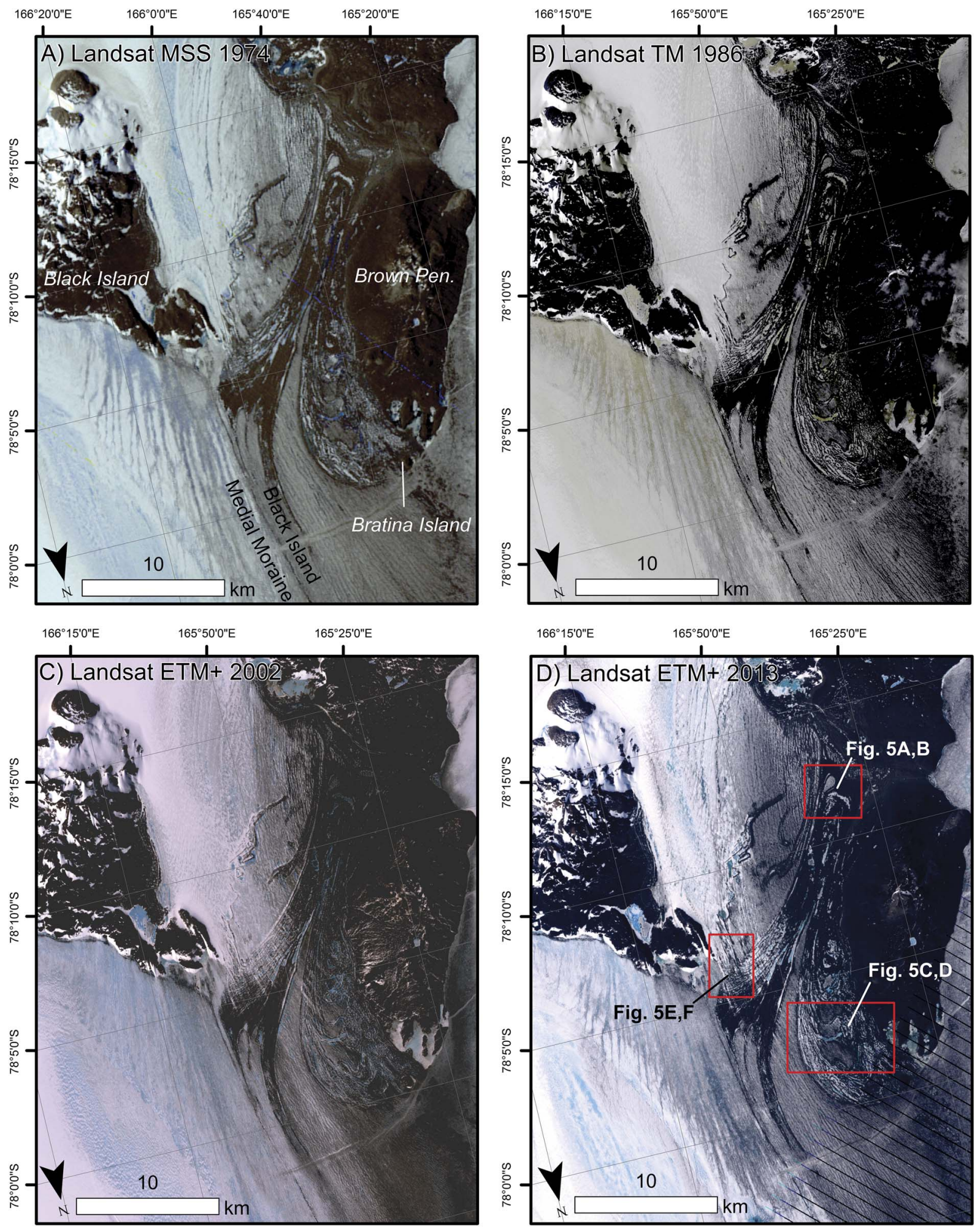

Fig. 4. Repeat satellite images showing debris in the 'swirls' area. a. Landsat MSS 1974. b. Landsat TM 1986. c. Landsat ETM+ 2002. d. Landsat ETM+ 2013. There is no discernable movement in the debris over this 39 -year period. Black lines in d. are an artefact of the failure of the Scanning Line Corrector on the Landsat instrument. 
debris bands usually has $\delta^{18} \mathrm{O}$ values ranging from -5.0 to $+5.0 \%$, indicating a marine origin. The presumed northward pattern of modern ice movement has been discussed above. The second type of debris band is located primarily along the east coast of Brown Peninsula in the 'swirls' area (Fig. 2). In this area, debris thickness appears to exceed $10 \mathrm{~cm}$ but its full extent has not been determined because it is ice-cemented below this depth. Boulders have lithologies indicating transport from the Transantarctic Mountains. Some of the debris bands cross the tidal crack along the MIS grounding line and extend onto the flanks of Brown Peninsula, and even cross the Brown Peninsula saddle. Shells from the northern part of the 'swirls' and adjacent bands yield ${ }^{14} \mathrm{C}$ ages $>20000 \mathrm{yr} \mathrm{BP}$, although these ages may be unreliable as radiocarbon dating in Antarctica is problematic due to reworking of old carbon. Ice samples from this area yield $\delta^{18} \mathrm{O}$ values between -25.35 and $-48.96 \%$, suggesting the presence of patches of glacial ice that formed at elevations $>3000 \mathrm{~m}$ and subsequently advected to southern McMurdo Sound. There is also a minor component of aeolian material on the ice shelf surface (Dunbar et al. 2009).

From a structural glaciological and debris transport perspective, the most interesting parts of the MIS are those areas where surface debris is concentrated into landforms. These are: i) a complicated area of debris commonly referred to as the 'swirls', upstream of Bratina Island (Figs 2, 3 \& 4) (Kellogg et al. 1990) where there is almost continuous surface debris between Black Island and Brown Peninsula whose origin remains unclear; ii) the Black Island medial moraine, a linear feature that stretches from Black Island to the ice shelf edge (Fig. 1).

Detailed field sedimentological descriptions and textural data on the debris in the 'swirls' area and the Black Island medial moraine are presented in Glasser et al. (2006). Four main sediment-landform assemblages have been recognized: the Black Island medial moraine, isolated gravel patches, Bratina Island moraines, and ice cored ridges and cones.

The Black Island medial moraine comprises a linear chain of large (up to $5 \mathrm{~m}$ high), ice cored debris cones and ridges separated by intervening meltwater ponds. Individual debris cones and ridges are texturally variable but are typically composed of sandy gravel, sandy pebblegravel or sandy cobble-gravel. This feature is interpreted as basally derived supraglacial material forming a medial moraine.

Isolated gravel patches, thin isolated patches of wellsorted sand and granule gravel, are present on the ice shelf surface either side of the Black Island medial moraine. This thin debris creates a low relief $(<1 \mathrm{~m}$ relative relief) landscape of ice cored cones and ridges, separated by small (generally metre-scale) meltwater streams and ponds. Patches of gravel occur on the banks of active meltstreams. Gravel-sized clasts are sub-angular, sub-rounded and rounded, of mixed lithology (although dominated by locally derived, fine-grained volcanic rocks) and do not bear striations or facets. These patches are probably the product of small-scale reworking and redistribution of the debris in the larger Black Island medial moraine by supraglacial streams and meltwater ponds.

The Bratina Island moraines, a group of large, subhorizontal, curvilinear moraines, are wrapped around the lower slopes of Bratina Island moraine. Individual ridges vary in their composition, but the majority are composed of sandy gravel. Gravel-sized clasts in the sandy gravel are mainly sub-rounded with occasional sub-angular and rounded clasts, of mixed lithology and do not bear striations or facets. The Bratina Island moraines are interpreted as accumulations of sediment formed where the contemporary (but vertically more extensive) MIS abuts the land.

Ice cored ridges and cones surrounding Bratina Island form individual mounds of sandy gravel, gravelly sand, sandy pebble-gravel or diamicton, often containing scattered fossil marine shells and contemporary faunal remains. Individual mounds are separated by large (100 metre-scale) meltwater ponds. Active failures and exposures in the walls of the mounds reveal bare ice beneath and show that the ice shelf surface sediments are generally thin (up to $0.1 \mathrm{~m}$ ), attaining a maximum thickness of $0.5 \mathrm{~m}$. There is no obvious source area for the large volumes of supraglacial material present on the contemporary ice shelf surface. The clast roundness and lithology (including the presence of Transantarctic Mountain metasedimentary rocks) indicates that this material originated outside the current extent of the ice shelf. These ridges and cones are interpreted as material that was transported into the McMurdo Sound area by a larger and more dynamically active ice sheet or ice shelf.

This paper will concentrate on the overall styles of deformation represented by these areas of debris on the ice shelf and the inferences that can be drawn from the deformation and its relationship to modern ice surface structures and velocities derived from remote-sensing studies.

\section{Methods}

\section{Ice shelf velocities}

Ice shelf velocities were taken from the MEaSUREs dataset and represent the surface dynamics from $c$. 2010, calculated using speckle tracking interferometry with RADARSAT-2 data (Rignot et al. 2011). These data carry a maximum error of $\pm 2 \mathrm{ma}^{-1}$. Flow vectors were calculated from the $x$ and $y$ binary data using the COSI-Corr software in ENVI 4.6. The position of the grounding line was added from the Bedmap2 dataset (Fretwell et al. 2013). 

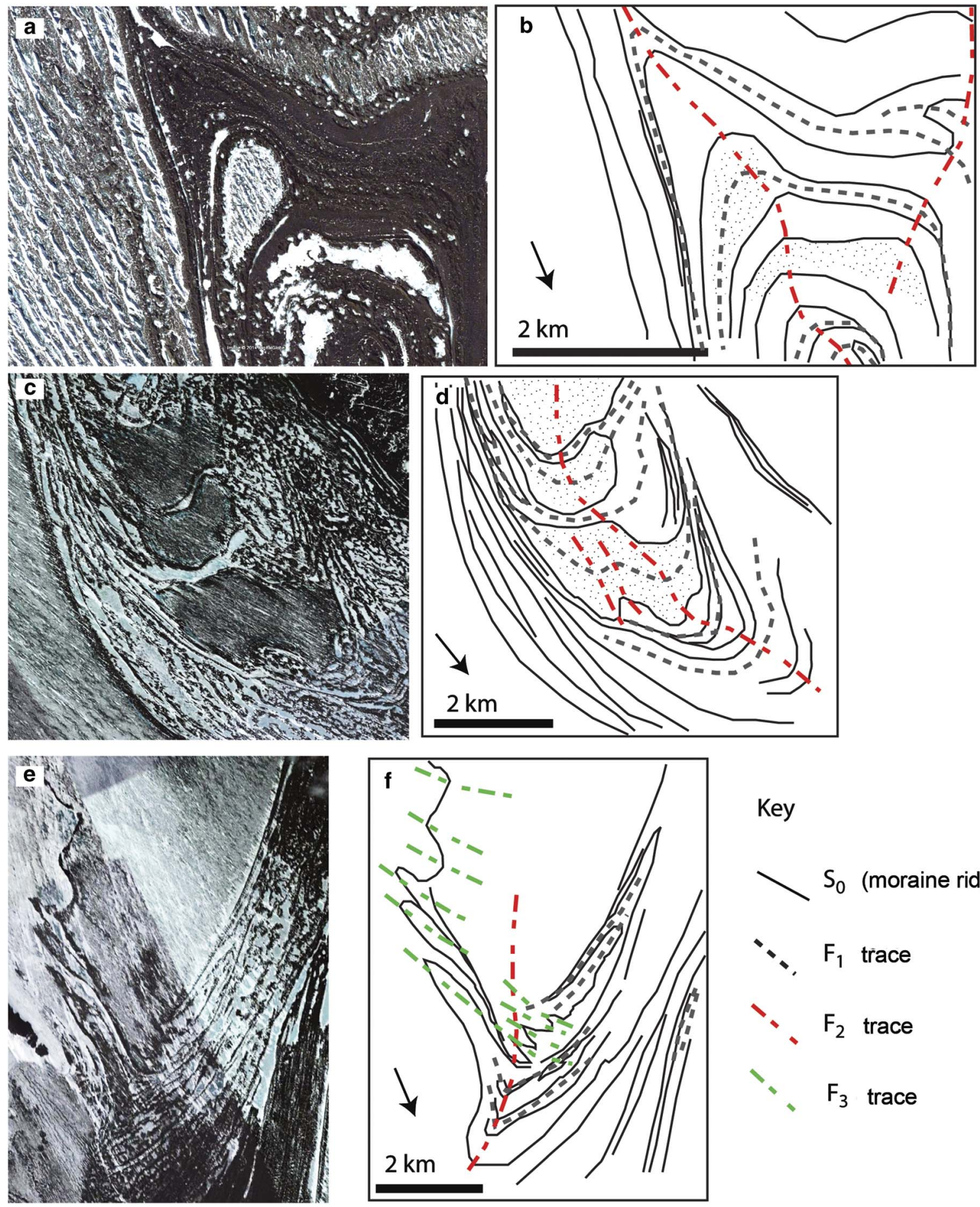

Key

$\mathrm{S}_{0}$ (moraine ridges)

$\because F_{1}$ trace

$\checkmark F_{2}$ trace

$\because F_{3}$ trace

Fig. 5. Detailed analysis of folded debris on the surface of the McMurdo Ice Shelf. Locations shown in Fig. 4. These examples show the sequence of folding and refolding illustrated in Fig. 7.

\section{Structural analysis}

Debris ridges on the MIS were mapped from Advanced Spaceborne Thermal Emission and Reflection Radiometer (ASTER) satellite images from 2001 onwards. Folded debris ridges were traced manually from the ASTER imagery, and described using basic structural geology principles (e.g. Ramsay 1967, Ramsay \& Huber 1987). It is difficult to infer the dip of individual layers that protrude from the ice surface to form ridges from satellite images. However, their formation is probably due to buckling of an initial horizontal layer to form gently 

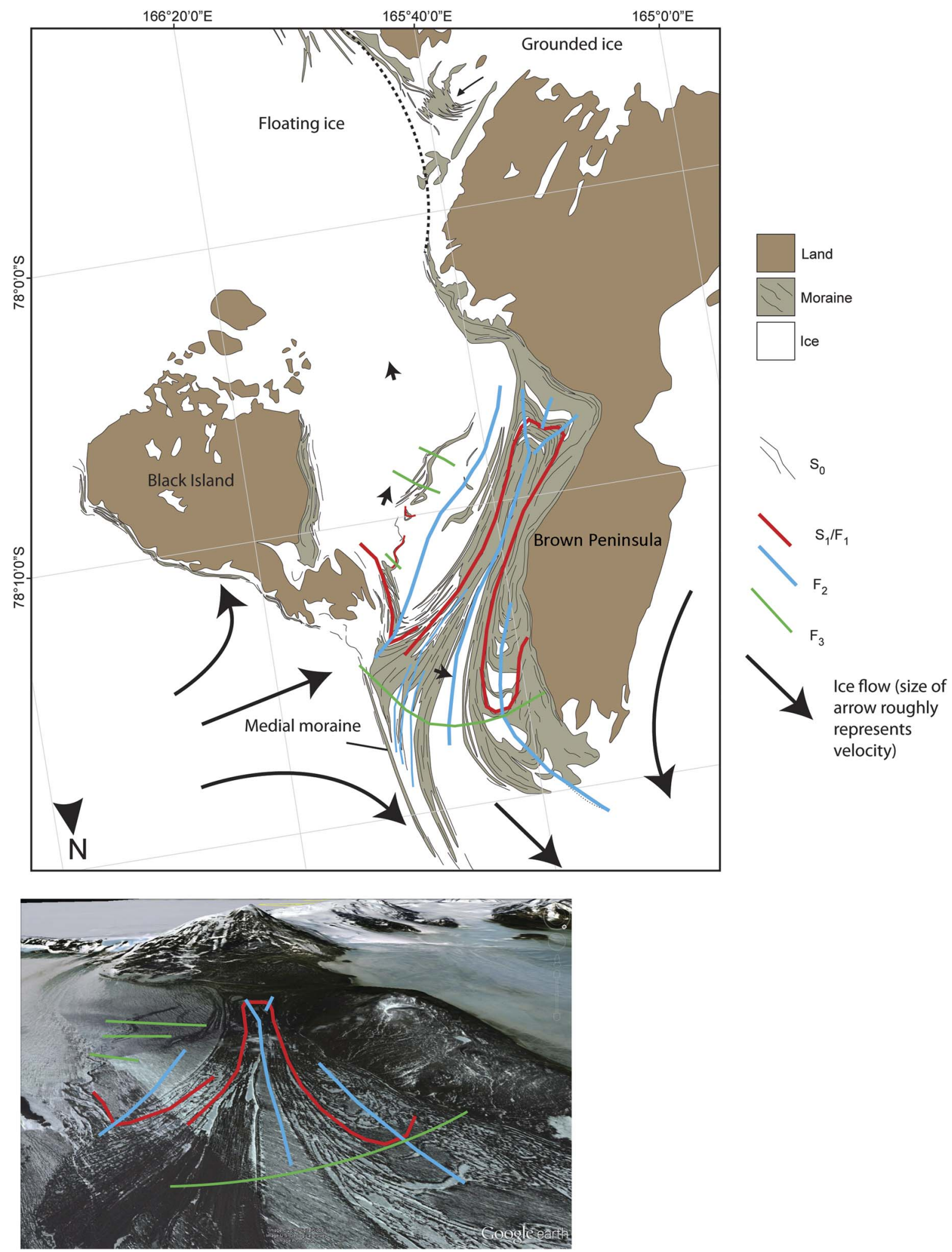

Fig. 6. a. Structural interpretation using fold generations to indicate the sequence of folding and refolding of debris on the surface of the McMurdo Ice Shelf (MIS). b. Oblique view across the surface of the MIS from Google Earth (roughly south). 

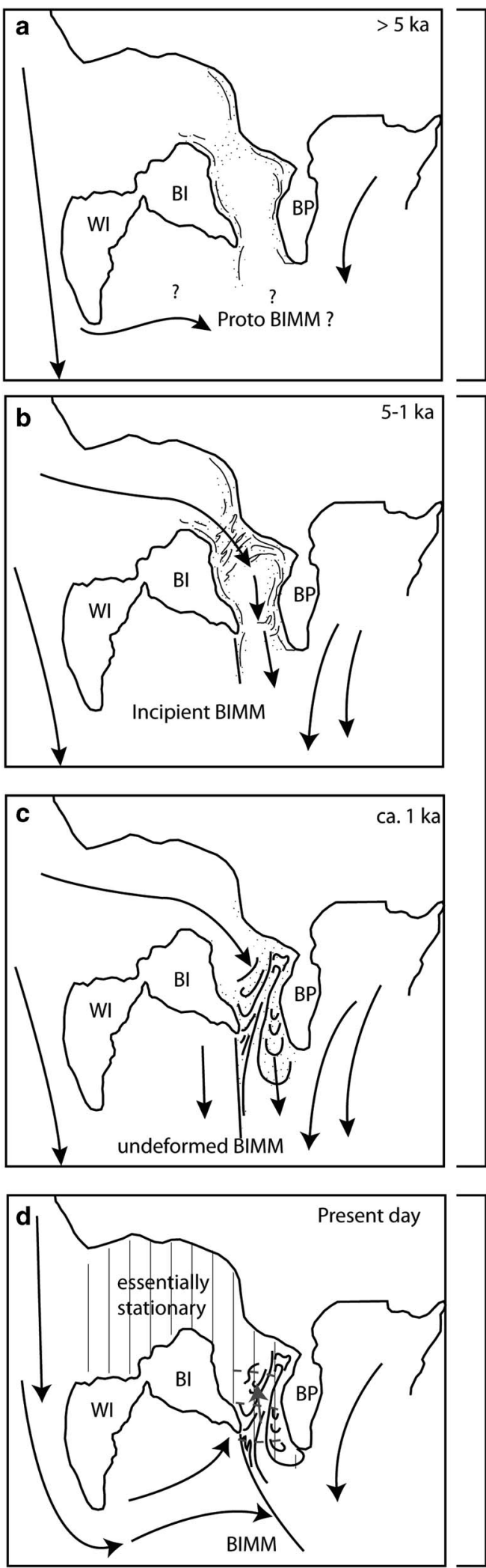

Sediment collecting on ice

surface (SO)

Stage 1

Ice flowing into the McMurdo Ice Shelf from the Ross Ice Shelf

Moraine ridges forming and beginning to buckle (S1/F1)

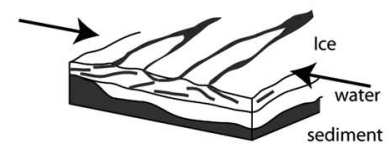

Stage 2

Ridges bunch up against Brown Peninsula and form incipient swirls due to rotation of initial (F1) ridges to form F2 loops and swirls

Ice extruded between Black Island and Brown Peninsula possibly faster than the ice flowing north from Black Island to form a

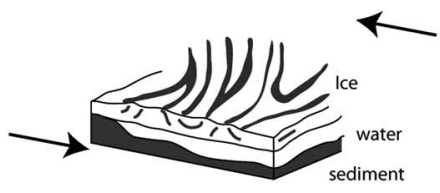
prominant lobe

Ice flowing into the McMurdo Ice Shelf from the Ross Ice Shelf is cut off and re-directed around White Island

Stage 3

Some late minor folding created as ice may even

be pushed back into

McMurdo Sound (F3)

Fig. 7. Schematic sequence of folding and refolding of debris. The sequence is summarized in three stages. a. Stage 1 shows initial conditions c. $5 \mathrm{ka}$. b. and c. Stage 2 shows the development of ice flow into McMurdo Sound to create folded moraine ridges. d. Stage 3 marks the return of ice flow around White Island (WI) and re-orientation of the Black Island medial moraine (BIMM). $\mathrm{BI}=$ Black Island, $\mathrm{BP}=$ Brown Peninsula. 
plunging and largely symmetrical and upright folds. Further flow of the ice will tend to: i) tighten initial buckle folds and ii) rotate the fold axes about the vertical axes. The pattern of swirls and loops can be analysed in a similar way to fold interference patterns in polyphase deformed rocks. The technique focuses on identifying hinge points (points of maximum curvature) from the folded debris ridges to define axial traces (2D map or section expression of a fold axial surface) which allow generations of folding to be identified by their superposition (Ramsay 1967).

\section{Results}

Description of ice shelf velocities

The MIS had a low surface velocity, with the 'swirls' area averaging speeds of $c .3 \mathrm{~m} \mathrm{a}^{-1}$ increasing to $c .16 \mathrm{~m} \mathrm{a}^{-1}$ at the ice front (Fig. 1). The area between Minna Bluff and the White and Black islands also had low surface velocities (c. $3 \mathrm{~m} \mathrm{a}^{-1}$ ), with flow direction parallel to the grounding line of Minna Bluff and Mount Discovery, towards the channel between Black Island and Brown Peninsula. The most dynamic component existed where the Ross Ice Shelf lobe rounds the northern tip of White Island and flows towards Black Island and the Black Island medial moraine complex, before being forced to flow north-west as it impinges on the slower moving ice between Black Island and Brown Peninsula. There was a subtle increase in flow speed (from $c .3 \mathrm{~m} \mathrm{a}^{-1}$ to $c .12 \mathrm{~m} \mathrm{a}^{-1}$ ) as ice flowed out of the channel between Black Island and Brown Peninsula, passed Bratina Island (Fig. 1).

\section{Structural glaciology}

On the eastern side of Brown Peninsula (Fig. 4a), the debris forms spectacular patterns. Treating these patterns as fold traces, up to three generations of folding were distinguished by identifying hinge points (Fig. 5). The hinge points of a single generation of tectonic folding (folds generated in an ambient strain field and not from internal body forces such as gravity) usually line up across several layers when there is no major rheological contrast or mechanical discontinuity between layers (Fig. 6). It is difficult to infer true fold geometry without knowing the true attitude of the foliation, but it is probable that the folded sequence began as buckling of initially horizontal layers or patches of debris due to flow of the ice. The first folds $\left(F_{1}\right)$ were probably gently or negligibly plunging, upright and symmetrical (Fig. 7). Fold tightness was difficult to estimate but it was not important in this context as refolding is more useful in tracking the evolution of ice flow. Further flow would tend to tighten the initial buckle folds and rotate them about the vertical axes. This describes $F_{2}$ interference where the initially horizontal fold axes are rotated about the vertical axes.
There may be local departures from this toward $\mathrm{F}_{3}$ or $\mathrm{F}_{1}$, potentially due to greater rotation or simple shear near the margins of the ice. Although the initial folds were probably very gently plunging, slight plunges are sufficient to enable identification of early fold hinges on a flat horizontal surface. The sequence of deformation and relevant structures are shown in Fig. 7. The primary linear debris traces (moraine ridges) on the ice surface are represented by $S_{0}$, which can be used as a strain marker in a similar way to $S_{0}$ stratification in valley glaciers. These were probably initially formed by upward transport of debris through the ice at or near the grounding line, facilitated by high surface ablation rates. In some cases, subsequent deformation due to shear between the flowing ice and the grounding line $\left(\mathrm{S}_{1} / \mathrm{F}_{1}\right)$ has occurred. This resulted in buckling of the initially horizontal $\mathrm{S}_{0}$ to form the linear arrangements visible on the ice surface. The linear ridges are folded about upright, symmetrical and gently plunging folds identified as $F_{1}$ fold closures at hinge points along traces of $\mathrm{S}_{0}$. The $\mathrm{F}_{2}$ folds are characterized by at least three large-scale folds that trend NNE-SSW and appear markedly pinched or squeezed to the north and west of Brown Peninsula. These refold $F_{1}$ traces and occasionally parasitic $\mathrm{F}_{2}$ folds can be identified. The $F_{3}$ folds form where $F_{2}$ folds are refolded by the youngest generation of folding. These folds cross-cut all previous folding and are only evident occasionally between Black Island and Brown Peninsula, but are delineated by sinistral (anti-clockwise) rotation of the entire foliation pattern to the south-west of Brown Peninsula.

\section{Structural interpretations}

\section{Initial 'swirls' development $\left(S_{0}\right)$}

Within the 'swirls', the moraine ridges appear to have been subjected to multiple phases of deformation (Figs 5, $6 \& 7$ ). Ice surface moraines $\left(S_{0}\right.$ in Figs $\left.5 \& 6\right)$, with a similar surface appearance can be observed forming at the grounding zone (e.g. adjacent to Minna Bluff). Material may have become incorporated into the ice either through grounding of the ice shelf to the sea bed at these marginal locations, or through the inclusion of anchor ice (Debenham 1919, Mager et al. 2013), where high ablation rates facilitate the upward transport of material through the ice to the surface. Once at the surface, the material remains exposed and, if thick enough, can shield underlying ice from surface ablation. On the ice surface, these moraines move with the flow of the ice and act as a passive strain marker for ice flow. Thus, patches become stretched out, attenuated and occasionally folded into linear ridges during deformation. Assuming that these patches had an irregular arrangement to begin with, the resultant pattern on the ice surface can be used to infer a time-averaged 2-D (plane) strain record. Debris patterns 


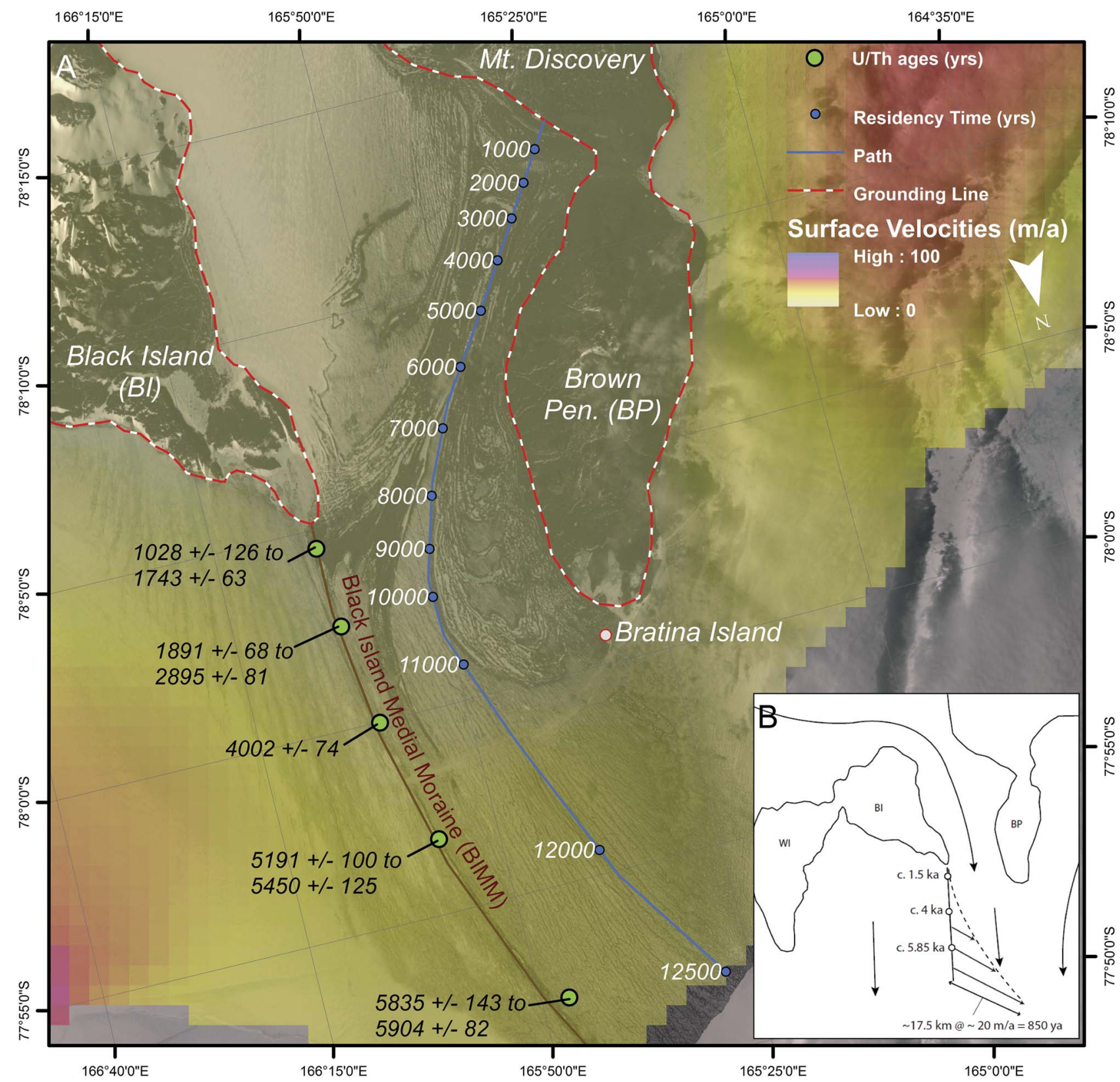

Fig. 8. a. Calculated residency time for surface debris entering the ice shelf at the Mount Discovery grounding line and leaving the ice shelf at the calving front, assuming modern surface velocities, ice shelf stability through the Holocene, and current geometric configuration. Ice surface debris ages (from Hall et al. 2010) indicating the min-max U-Th ages for shells found in the Black Island medial moraine (BIMM) are also shown. Both datasets show that a particle would take $c .4500$ years to travel from Black Island to the ice front. These data indicate that the ice shelf has been in its current configuration for at least $5 \mathrm{ka}$. b. Re-orientation of the BIMM during the past 1 ka inferred from structural relationships shown in Fig. 7.

do not record the total finite strain as they were deforming during their genesis but ridges represent lines of plane strain and fold hinges can be used to demonstrate interference of folding. Furthermore, it may be possible for moraines to 'peel off' from the margins and be transported towards more central areas of the ice shelf. This could occur through the growth of new ice at tidal cracks at the ice shelf margin or through the input of glacier ice from tributary glaciers flowing into the ice shelf (e.g. south of Black Island).

\section{Flow (strain) history}

The evolution of the 'swirls' area and the Black Island medial moraine are incompatible with the current ice flow configuration. The moraine ridges in the 'swirls' area have 
been deformed in response to NW-SE shortening as ice from the south-east reached a constricted area between the Brown Peninsula and Black Island. As such, moraines which may have originally formed parallel to ice margins have been rotated and deformed, forming folds $\left(\mathrm{F}_{2}\right.$ in Figs $5 \& 6$ ). There may have been some north-west and south-east extrusion of the ice along the south-west coast of Brown Peninsula (Kellogg et al. 1990) producing some constriction of flow between Brown Peninsula and Black Island, caused by impingement on the coastline.

At the junction between the 'swirls' and the Black Island medial moraine there appears to be a zone of sinistral simple shear where the ridges are rotated anti-clockwise from a dominant NNE trend to a NNW trend, and are either attenuated or truncated (Fig. 6b). This discontinuity may represent a relict shear zone between the 'swirls' area and the Ross Ice Shelf to the south of Black Island, but this is not supported by current ice velocities. The Black Island medial moraine was probably rotated into this position by the current ice velocity as the ice between Black Island and the Brown Peninsula is near-stationary or very slow moving. This discontinuity is apparent and simply an abrupt change in pure shear strain during Stage 3 deformation. This switch has also, in places, resulted in the refolding and rotation of $F_{2}$ folds, forming $F_{3}$ structures (Fig. 7).

Contemporary ice velocities are c. $20 \mathrm{ma}^{-1}$ at the northern end of the Black Island medial moraine and c. $0 \mathrm{~m} \mathrm{a}^{-1}$ close to Black Island. Thus, the Black Island medial moraine has re-orientated to a virtually straight line on a bearing east of north (Fig. 8). The Black Island medial moraine probably formed at the confluence of ice between Black Island/Brown Peninsula and the Ross Ice Shelf, south of Black Island. This may have been a temporary event, possibly due to a temporary increase in ice velocity from the MIS or a function of a thicker and more horizontally expanded Ross Ice Shelf.

\section{Implications for past ice shelf dynamics and stability}

The present ice surface debris configuration is inconsistent with the contemporary ice flow configuration in the area. To produce the $S_{1}$ folding, large amounts of ice shortening has resulted from past ice flow from the SSE. The velocity measurements indicate that the ice shelf in this area is very slow moving (near-stationary), which is inconsistent with this style of folding. Furthermore, the identification of $F_{2}$ structures suggests that the area has been affected by a subsequent phase of deformation. This deformation was probably due to a stagnation of ice flow between Brown Peninsula and Black Island and a switch in the ice flow south of the debris to a westerly or north-westerly orientation, consistent with the current velocity orientations. This evidence of polyphase folding suggests at least one period of more dynamic ice shelf flow in the past. Therefore, the inference is that ice formerly flowed into the MIS causing ice to flow out of the strait between Black Island and Brown Peninsula forming the 'swirls' and the Black Island medial moraine. Ice flow subsequently diminished and the Black Island medial moraine rotated to its current configuration.

The InSAR data (Rignot et al. 2011), field data (Glasser et al. 2006) and flow rates derived from ${ }^{14} \mathrm{C}$ and $\mathrm{U}-\mathrm{Th}$ dating of corals on the ice surface (Hall et al. 2010) show that the ice shelf moves relatively slowly $\left(1.5-18.3 \mathrm{~m} \mathrm{a}^{-1}\right)$. Large areas of surface debris in the 'swirls' area have no source area on the ice shelf and must represent deformation of pre-existing surface material that cannot be related to contemporary flow. Therefore, the spatially extensive areas of debris on the ice shelf surface represent the debris load of a grounded ice sheet/ice shelf system under a wholly different dynamic regime, that is effectively stranded on the ice shelf surface in an area of low velocity. Kellogg et al. (1996) similarly concluded that the 'swirls' area includes deformed remnants from the grounded late Wisconsin Ross Sea ice sheet. Glacial flow was apparently directed from east-west across southern McMurdo Sound. The low contemporary ice surface velocities, coupled with high surface ablation rates, mean that this debris was not carried to the ice shelf edge and lost to calving processes. The Black Island medial moraine may represent debris accumulated along a former flow-unit boundary which, under the contemporary flow regime, is now being redistributed across the ice shelf surface.

Glasser et al. (2006) suggested that the majority of debris on the ice shelf was originally transported into the area by a large and dynamic ice sheet/ice shelf system at the last glacial maximum (LGM). There are two existing models for ice sheet/ice shelf interactions in the Ross Sea-McMurdo Sound area in the late Pleistocene and Holocene. The first of these hypotheses is that at the LGM the area was inundated by a grounded ice sheet that filled the entire Ross Sea embayment (Denton et al. 1989, Kellogg et al. 1990). In this model, ice flowed from east-west across McMurdo Sound. The second model invokes grounded ice but suggests that three co-existing ice lobes flowed into the area (Wilson 2000). These lobes were an expanded and grounded Koettlitz Glacier lobe, a Ross Ice Shelf lobe and a smaller medial lobe fed from grounded ice in the Ross Sea that flowed between Brown Peninsula and Black Island. Our interpretation of the debris stranded on the ice shelf surface in the 'swirls' area is most easily accommodated by the model of Wilson (2000), in which this debris represents the deformed remnants of a set of moraines marking the extent of a tongue of ice that flowed between Brown Peninsula and Black Island. This suggests that the MIS has been a permanent feature through the late Pleistocene and Holocene, although it has probably thinned during this time.

Hall et al. (2010) derived ice shelf flow rates for the MIS from ${ }^{14} \mathrm{C}$ and $\mathrm{U}$-Th dating of the emergence of corals 
along the Black Island medial moraine. Coral ages range from $1038 \pm 126 / 1743 \pm 63 \mathrm{ka}$ at Black Island to $5835 \pm 143 / 5904 \pm 82 \mathrm{ka} c .29 \mathrm{~km}$ near the ice front. This indicates that particles take c. $4.5 \mathrm{ka}$ to travel from Black Island to the ice front. The coral ages indicate that ice surface velocities increase from $c .2 \mathrm{ma}^{-1}$ at the present grounding zone near Black Island to $c .11 \mathrm{~m} \mathrm{a}^{-1}$ near the calving front. The velocity data also indicates a similar length of time is required to travel this distance (Fig. 8). In combination, these data indicate that the ice shelf has been in its current configuration for at least $5 \mathrm{ka}$, i.e. since at least the mid-Holocene, but possibly even longer, suggesting that the MIS is a relatively persistent and stable feature.

\section{Conclusions}

The present ice surface debris configuration on the MIS reveals a deformational history inconsistent with the current ice flow configuration in the area. The polyphase folding of the deformed moraines infer that there has been at least one period of more dynamic ice shelf flow. Ice formerly flowed into the MIS from an external source area, forcing ice through the strait between Black Island and Brown Peninsula, thus deforming ice surface debris, thereby creating the 'swirls' and the Black Island medial moraine. Ice flow subsequently diminished and the Black Island medial moraine rotated to its current configuration. Calculated flow rates indicate that the MIS is a relatively persistent and stable feature, which has probably been in its present configuration since at least the mid-Holocene, and possibly even longer.

\section{Acknowledgements}

We thank the two journal reviewers, Emrys Philips and an anonymous reviewer, for their constructive comments which helped us improve this paper.

\section{Author contributions}

NFG led the study and contributed field data on ice shelf processes and surface sediments. TH contributed remotely sensed data, including the ice shelf velocity analysis. EF and CS contributed descriptions and interpretations of styles of surface-debris deformation. All authors contributed to the writing of the manuscript.

\section{References}

Albrecht, N., Vennell, R., Williams, M., Stevens, C., Langhorne, P., Leonard, G. \& Haskell, T. 2006. Observation of sub-inertial internal tides in McMurdo Sound, Antarctica. Geophysical Research Letters, 33, 10.1029/2006GL027377.

Barrand, N.E., Vaughan, D.G., Steiner, N., Tedesco, M., Munneke, P.K., van den Broeke, M.R. \& Hosking, J.S. 2013. Trends in Antarctic Peninsula surface melting conditions from observations and regional climate modelling. Journal of Geophysical Research - Earth Surface, 118, 315-330.
Berthier, E., Scambos, T.A. \& Shuman, C.A. 2012. Mass loss of Larsen B tributary glaciers (Antarctic Peninsula) unabated since 2002. Geophysical Research Letters, 39, 10.1029/2012GL051755.

Brady, H.T. 1978. Geological studies in southern Victoria Land, on Black Island, and on the McMurdo Ice Shelf. Antarctic Journal of the United States, 13, 13-14.

Cook, A.J. \& VAughan, D.G. 2010. Overview of areal changes of the ice shelves on the Antarctic Peninsula over the past 50 years. Cryosphere, 4, 77-98.

Cook, J.C. 1963. Seismic reconnaissance on an ice-covered Antarctic sea. Journal of Glaciology, 4, 559-568.

Craven, M., Allison, I., Fricker, H.A. \& Warner., R. 2009. Properties of a marine ice layer under the Amery Ice Shelf, East Antarctica. Journal of Glaciology, 55, 717-728.

De Angelis, H. \& Skvarca, P. 2003. Glacier surge after ice shelf collapse. Science, 299, 1560-1562.

Debenham, F. 1919. A new mode of transportation by ice: the raised marine muds of south Victoria Land (Antarctica). Quarterly Journal of the Geological Society, 75, 51-76.

Debenham, F. 1961. A fish story from the Antarctic. Geographical Magazine, 34, 360-368.

Debenham, F. 1965. The genesis of the McMurdo Ice Shelf, Antarctica. Journal of Glaciology, 5, 829-832.

Dempsey, D.E., Langhorne, P.J., Robinson, N.J., Williams, M.J.M., HASKell, T.G. \& Frew, R.D. 2010. Observation and modeling of platelet ice fabric in McMurdo Sound, Antarctica. Journal of Geophysical Research - Oceans, 115, 10.1029/2008JC005264.

Denton, G.H., Bockheim, J.G., Wilson, S.C. \& Stuiver, M. 1989. Late Wisconsin and early Holocene glacial history, inner Ross embayment, Antarctica. Quaternary Research, 31, 151-182.

Dunbar, G.B., Bertler, N.A.N. \& McKay, R.M. 2009. Sediment flux through the McMurdo Ice Shelf in Windless Bight, Antarctica. Global and Planetary Change, 69, 87-93.

Fretwell, P., Pritchard, H.D., Vaughan, D.G. \& 57 others. 2013. Bedmap2: improved ice bed, surface and thickness datasets for Antarctica. Cryosphere, 7, 375-393.

Fitzsimons, S., Mager, S., Frew, R., Clifford, A. \& Wilson, G. 2012. Formation of ice-shelf moraines by accretion of sea water and marine sediment at the southern margin of the McMurdo Ice Shelf, Antarctica. Annals of Glaciology, 53, 211-220.

Glasser, N.F., Goodsell, B., Copland, L. \& Lawson, W. 2006. Debris characteristics and ice-shelf dynamics in the ablation region of the McMurdo Ice Shelf, Antarctica. Journal of Glaciology, 52, 223-234.

Glasser, N.F., Scambos, T.A., Bohlander, J., Truffer, M., Pettit, E. \& DAvies, B.J. 2011. From ice-shelf tributary to tidewater glacier: continued rapid recession, acceleration and thinning of Röhss Glacier following the 1995 collapse of the Prince Gustav Ice Shelf, Antarctic Peninsula. Journal of Glaciology, 57, 397-406.

Gough, A.J., Mahoney, A.R., Langhorne, P.J., Williams, M.J.M., Robinson, N.J. \& Haskell, T.G. 2012. Signatures of supercooling: McMurdo Sound platelet ice. Journal of Glaciology, 58, 38-50.

Gow, A.J. 1967. Antarctic glaciological studies. Antarctic Journal of the United States, 2, 121-122.

Gow, A.J., Weeks, W.F., Hendrickson, G. \& Rowland, R. 1965. New light on the mode of uplift of the fish and fossiliferous moraines of the McMurdo Ice Shelf, Antarctica. Journal of Glaciology, 5, 813-828.

Hall, B.L., Henderson, G.M., Baroni, C. \& Kellogg, T.B. 2010. Constant Holocene Southern-Ocean ${ }^{14} \mathrm{C}$ reservoir ages and ice-shelf flow rates. Earth and Planetary Science Letters, 296, $115-123$.

HART, C.P. 1990. Holocene megafauna in McMurdo Ice Shelf sediments fossilization and implications for glacial processes. Antarctic Journal of the United States, 25(2), 11-14. 
Hawes, I., Smith, R., Howard-Williams, C. \& Schwarz, A.M. 1999. Environmental conditions during freezing, and response of microbial mats in ponds of the McMurdo Ice Shelf, Antarctica. Antarctic Science, 11, 198-208.

Hayward, P.J. \& TAYloR, P.D. 1984. Fossil and recent Cheilostomata (Bryozoa) from the Ross Sea, Antarctica. Journal of Natural History, 18, 71-94.

Hellmer, H.H. 2004. Impact of Antarctic ice shelf basal melting on sea ice and deep ocean properties. Geophysical Research Letters, 31, 10.1029/2004GL019506.

Hillenbrand, C.D., Kuhn, G., Smith, J.A., Gohl, K., Graham, A.G.C., Larter, R.D., Klages, J.P., Downey, R., Moreton, S.G., Forwick, M. \& VAughan, D.G. 2013. Grounding-line retreat of the West Antarctic Ice Sheet from inner Pine Island Bay. Geology, 41, 35-38.

Hulbe, C.L., MacAyeal, D.R., Denton, G.H., Kleman, J. \& Lowell, T.V. 2004. Catastrophic ice shelf breakup as the course of Heinrich event icebergs. Paleooceanography, 19, 10.1029/2003PA000890.

Jacobs, S.S., Hellmer, H.H., Doake, C.S.M., Jenkins, A. \& Frolich, R.M. 1992. Melting of ice shelves and the mass balance of Antarctica. Journal of Glaciology, 38, 375-387.

Joughin, I. \& PADMAn, L. 2003. Melting and freezing beneath FilchnerRonne Ice Shelf, Antarctica. Geophysical Research Letters, 30, 10.1029/2003GL016941.

KellogG, D.E. \& KellogG, T.B. 1984. Diatoms from the McMurdo Ice Shelf, Antarctica. Antarctic Journal of the United States, 19(5), 76-77.

KellogG, D.E. \& Kellogg, T.B. 1987a. Diatoms of the McMurdo Ice Shelf, Antarctica: implications for sediment and biotic reworking. Palaeogeography, Palaeoclimatology, Palaeoecology, 60, 77-96.

KellogG, D.E. \& KellogG, T.B. 1987b. Reworking of biotic and sedimentary debris on the McMurdo Ice Shelf. Antarctic Journal of the United States, 22(5), 118-119.

KellogG, T.B. \& KellogG, D.E. 1988. Fish story from the Antarctic, II. Antarctic Journal of the United States, 23(5), 82-84.

Kellogg, T.B., Hughes, T.J. \& Kellogg, D.E. 1996. Late Pleistocene interactions of East and West Antarctic ice-flow regimes: evidence from the McMurdo Ice Shelf. Journal of Glaciology, 42, 486-500.

Kellogg, T.B., KellogG, D.E. \& Stuiver, M. 1990. Late Quaternary history of the southwestern Ross Sea: evidence from debris bands on the McMurdo Ice Shelf, Antarctica. Antarctic Research Series, 50, 25-56.

Kellogg, T.B., Stuiver, M., Kellogg, D.E. \& Denton., G.H. 1977. Marine microfossils on the McMurdo Ice Shelf. Antarctic Journal of the United States, 12(4), 82-83.

Kovacs, A. \& Gow, A.J. 1975. Brine infiltration in the McMurdo Ice Shelf, McMurdo Sound, Antarctica. Journal of Geophysical Research, 80, 1957-1961.

Kovacs, A., Gow, A.J. \& Cragin, J. 1982. The Brine Zone in the McMurdo Ice Shelf, Antarctica. Annals of Glaciology, 3, 166-171.

Leonard, G.H., Langhorne, P.J., Williams, M.J.M., Vennell, R., Purdie, C.R., Dempsey, D.E., Haskell, T.G. \& Frew, R.D. 2011. Evolution of supercooling under coastal Antarctic sea ice during winter. Antarctic Science, 23, 399-409.

MacAyeal, D.R., Scambos, T.A., Hulbe, C.L. \& Fahnestock, M.A. 2003. Catastrophic ice-shelf break-up by an ice-shelf-fragment-capsize mechanism. Journal of Glaciology, 49, 22-36.

Mager, S.M., Smith, I.J., Kempema, E.W., Thomson, B.J. \& Leonard, G.H. 2013. Anchor ice in polar oceans. Progress in Physical Geography, 37, 468-483.

Mahoney, A.R., Gough, A.J., Langhorne, P.J., Robinson, N.J., Stevens, C.L., Williams, M.M.J. \& Haskell, T.G. 2011. The seasonal appearance of ice shelf water in coastal Antarctica and its effect on sea ice growth. Journal of Geophysical Research, 116, 10.1029/2011JC007060.

MCCRAE, I.R. 1984. A summary of glaciological measurements made between 1960 and 1984 on the McMurdo Ice Shelf Antarctica. Report No. 360. Auckland: Department of Theoretical and Applied Mechanics, 93 pp.
Meredith, M.P. \& King, J.C. 2005. Rapid climate change in the ocean to the west of the Antarctic Peninsula during the second half of the 20th century. Geophysical Research Letters, 32, 10.1029/2005GL024042.

Pridmore, R.D., VANT, W.N. \& Cummings, V.J. 1995. Factors affecting the water clarity of ponds on the McMurdo Ice Shelf, Antarctica. Antarctic Science, 7, 145-148.

Pritchard, H.D., Ligtenberg, S.R.M., Fricker, H.A., Vaughan, D.G., van den Broeke, M.R. \& Padman, L. 2012. Antarctic ice-sheet loss driven by basal melting of ice shelves. Nature, 484, 502-505.

Purdie, C.R., Langhorne, P.J., Leonard, G.H. \& Haskell, T.G. 2006. Growth of first-year land fast Antarctic sea ice determined from winter temperature measurements. Annals of Glaciology, 44, 170-176.

RACK, W. \& Rотт, H. 2004. Pattern of retreat and disintegration of the Larsen B ice shelf, Antarctic Peninsula. Annals of Glaciology, 39, 505-510.

Rack, W., HaAs, C. \& Langhorne, P.J. 2013. Airborne thickness and freeboard measurements over the McMurdo Ice Shelf, Antarctica, and implications for ice density. Journal of Geophysical Research Oceans, 118, 5899-5907.

RAmSAy, J.G. \& Huber, M.I. 1987. The techniques of modern structural geology. Volume 2: Folds and fractures. London: Academic Press, 391 pp.

RAMSAY, J.G. 1967. Folding and fracturing of rocks. New York, NY: McGraw-Hill, 568 pp.

Rignot, E., Casassa, G., Gogineni, P., Krabill, W., Rivera, A. \& Thomas, R. 2004. Accelerated ice discharge from the Antarctic Peninsula following the collapse of Larsen B ice shelf. Geophysical Research Letters, 31, 10.1029/2004GL020697.

Rignot, E., Mouginot, J. \& Scheuchl, B. 2011. MEaSUREs InSARBased Antarctica Velocity Map. RADARSAT-2 data. Boulder, CO: National Snow and Ice Data Center. Available at: http://dx.doi.org/ 10.5067/MEASURES/CRYOSPHERE/nsidc-0484.001.

Rignot, E., Jacobs, S., Mouginot, J. \& Scheuchl, B. 2013. Ice-shelf melting around Antarctica. Science, 341, 266-270.

Robinson, N.J., Williams, M.J.M., Barrett, P.J. \& Pyne, A.R. 2010. Observations of flow and ice-ocean interaction beneath the McMurdo Ice Shelf, Antarctica. Journal of Geophysical Research - Oceans, 115, 10.1029/2008JC005255.

Scambos, T.A., Bohlander, J.A., Shuman, C.A. \& Skvarca, P. 2004. Glacier acceleration and thinning after ice shelf collapse in the Larsen B embayment, Antarctica. Geophysical Research Letters, 31, 10.1029/2004GL020670.

SPeden, I.G. 1962. Fossiliferous Quaternary marine deposits in the McMurdo Sound region, Antarctica. New Zealand Journal of Geology and Geophysics, 5, 746-777.

Stammerjohn, S.E., Martinson, D.G., Smith, R.C., Yuan, X. \& RIND, D. 2008. Trends in Antarctic annual sea ice retreat and advance and their relation to El Niño-Southern Oscillation and Southern Annular Mode variability. Journal of Geophysical Research - Oceans, 113, 10.1029/2007JC004269.

Stern, A.A., Dinniman, M.S., Zagorodnov, V., Tyler, S.W. \& Holland, D.M. 2013. Intrusion of warm surface water beneath the McMurdo Ice Shelf, Antarctica. Journal of Geophysical Research Oceans, 118, 7036-7048.

Swithinbank, C.W., Darby, D.G. \& Wohlschlag, D.E. 1961. Faunal remains on an Antarctic ice shelf. Science, 133, 764-766.

Swithinbank, C.W. 1970. Ice movement in the McMurdo Sound area of Antarctica. IASH \& SCAR Publication, 86, 472-487.

Vaughan, D.G. \& DoaKe, C.S.M. 1996. Recent atmospheric warming and retreat of ice shelves on the Antarctic Peninsula. Nature, 379, 328-331.

Vaughan, D.G., Marshall, G.J., Connolley, W.M., Parkinson, C., Mulvaney, R., Hodgson, D.A., King, J.C., Pudsey, C.J. \& Turner, J. 2003. Recent rapid regional climate warming on the Antarctic Peninsula. Climate Change, 60, 243-274.

WILSON, G.S. 2000. Glacial geology and origin of fossiliferouserraticbearing moraines, southern McMurdo Sound, Antarctica - an alternative ice sheet hypothesis. Antarctic Research Series, 76, 19-37. 